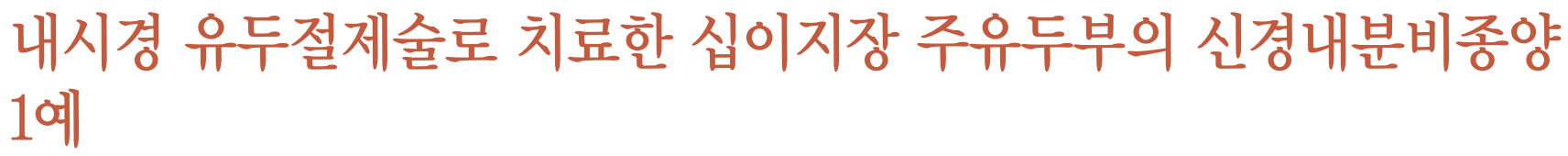

연세대학교 의과대학 강남세브란스병원 ${ }^{1}$ 내과, ${ }^{2}$ 병리과, ${ }^{3}$ 한림대학교 의과대학 강남성심병원 내과

윤홍진 ${ }^{1} \cdot$ 정영학 $^{1} \cdot$ 최성은 $^{2} \cdot$ 박정수 $^{1} \cdot$ 김용훈 $^{1} \cdot$ 김혜원 $^{1} \cdot$ 장성일 $^{3} \cdot$ 이동기 ${ }^{1}$

\title{
A Case of Ampullary Neuroendocrine Tumor Treated by Endoscopic Papillectomy
}

\author{
Hong Jin Yoon', Young Hak Jung', Sung Eun Choi ${ }^{2}$, Jung Soo Park', Yong Hoon Kim', Hae Won Kim', Sung III Jang ${ }^{3}$, \\ Dong Ki Lee' \\ Departments of 'Internal Medicine, ${ }^{2}$ Pathology, Gangnam Severance Hospital, Yonsei University College of Medicine, Seoul; \\ ${ }^{3}$ Departments of Internal Medicine, Kangnam Sacred Heart Hospital, Hallym University College of Medicine, Seoul, Korea
}

Ampullary neuroendocrine tumor is rare but requires total resection for treatment. Traditionally, pancreatic duodenal resection has been recommended for treatment of ampullary neuroendocrine tumor. Because of the morbidity and mortality associated with surgical resection, endoscopic papillectomy is increasingly used in selected cases with low grade, no metastasis, and no invasion of the pancreatic or bile duct. We present a case of an ampullary neuroendocrine tumor which was successfully and completely resected via endoscopic papillectomy. Endoscopic papillectomy can be a viable alternative for the resection of neuroendocrine tumor at the major duodenal papilla in cases with high surgical risks.

Korean J Pancreatobiliary 2014;19(4):204-209

Keywords: Neuroendocrine tumor, Carcinoid tumor, Ampulla of Vater, Endoscopy

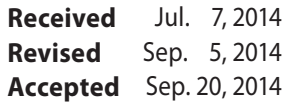

Corresponding author: Sung III Jang

Department of Internal Medicine, Kangnam Sacred Heart Hospital, Hallym University College of Medicine, 1 Singil-ro, Yeong deungpo-gu, Seoul 150-950, Korea

Tel. +82-2-829-5107 Fax. +82-2-846-4669

E-mail; aerojsi88@gmail.com

This is an Open Access article distributed under the terms of the Creative Commons Attribution Non-Commercial License (http:// creativecommons.org/licenses/by-nc/3.0/) which permits unrestricted non-commercial use, distribution, and reproduction in any medium, provided the original work is properly cited.

Copyright $\odot 2014$ by The Korean Journal of Pancreas and Biliary Tract

\section{서 론}

신경내분비종양은 위장관 전체에서 발생하며 주로 맹장 및 원위부 소장에서 가장 많이 발생한다. ${ }^{1}$ 십이지장 주유두 에서의 발생 빈도는 전체 위장관 신경내분비종양 중 0.3-1\% 로 매우 드물다. ${ }^{2}$ 신경내분비종양은 완전 절제할 경우 5 년 생
존율이 95\%로 예후가 전반적으로 좋아 수술적 완전 절제가 근치적 치료법이다. ${ }^{3}$ 특히 십이지장 주유두에서 발생하는 신 경내분비종양의 경우 드물게 전이를 동반하기 때문에 수술 적 완전 절제가 우선적인 치료법이다. ${ }^{1}$ 그러나 최근 동반질 병이 많거나 고령으로 인해 수술적 치료의 위험도가 높은 경 우 내시경 유두절제술이 시도되고 있다. 국외에서 3건이 시 


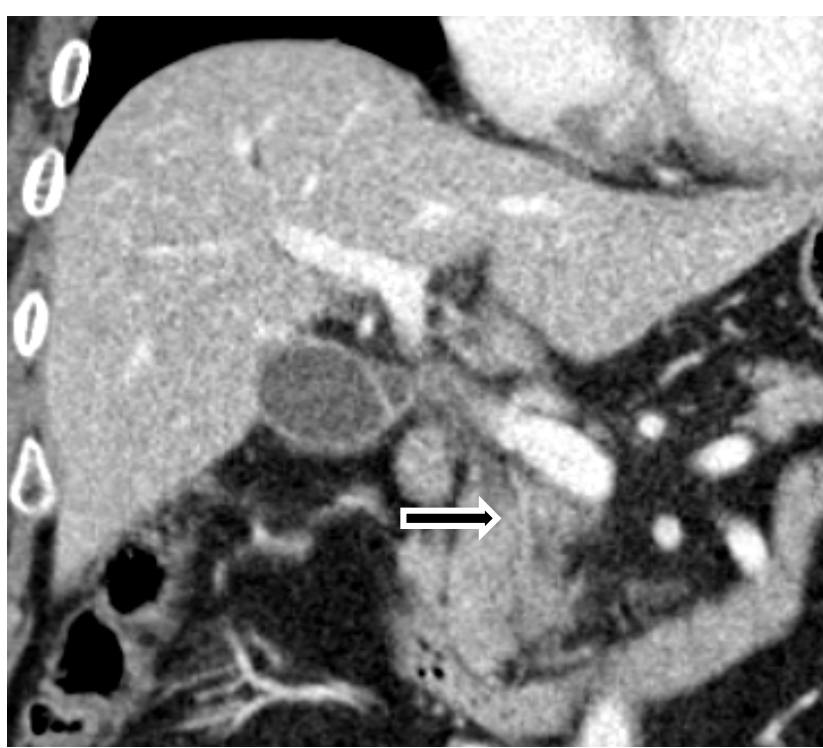

Fig. 1. A CT image shows a small common bile duct stone and mild bile duct dilatation.

도되었고, 국내에서도 내시경으로 완전 절제 이후 재발 없이 추적 관찰 중인 두 건의 증례가 보고되었다. ${ }^{4-8}$ 저자들은 담낭 결석에 의한 담낭염의 치료 과정에서 우연히 발견된 십이지 장 주유두의 신경내분비종양을 내시경 유두절제술로 치료 한 증례를 경험하였기에 문헌고찰과 함께 보고하는 바이다.

\section{증 례}

73세 남자 환자가 배꼽 주위 통증을 주소로 내원하였다. 복부 전산화 단층 촬영 $(\mathrm{CT})$ 상 담낭 결석을 동반한 급성 담낭 염 소견을 보였고 혈청화학 검사상 총 빌리루빈 $1.0 \mathrm{mg} / \mathrm{dL}$, AST 54 IU/L, ALT 33 IU/L, ALP (alkaline phosphatase) 115 $\mathrm{IU} / \mathrm{L}$, 아밀라아제 $48 \mathrm{U} / \mathrm{L}$, 리파아제 $36 \mathrm{U} / \mathrm{L}$ 로 응급 복강경하 담낭 절제술을 시행받았다. 그러나 수술 후에도 복부 통증이 지속되어 시행한 혈청화학 검사상 총 빌리루빈이 $5.7 \mathrm{mg} / \mathrm{dL}$ 로 상승하고, 직접 빌리루빈 $3.8 \mathrm{mg} / \mathrm{dL}, \mathrm{AST} 196 \mathrm{IU} / \mathrm{L}, \mathrm{ALT}$ 257 IU/L, ALP(alkaline phosphatase) 136 IU/L, $\gamma$-GT ( $\gamma$-glutamyltranspeptidase) $257 \mathrm{IU} / \mathrm{L}$ 로 담관의 폐쇄가 의심 되었다. 혈중 CEA (carcinoembryonic antigen) $3.1 \mathrm{ng} / \mathrm{mL}$, CA (carbohydrate antigen) 19-9 0.8 U/mL로 종양 표지자는 정상이었다. 내원 시 시행한 $\mathrm{CT}$ 상에서 총담관내 담석이 의 심되고 경도의 담관 확장 소견을 보여(Fig. 1) 내시경적 역행 성 췌담도조영술 $(\mathrm{ERCP})$ 시행하였다. $\mathrm{ERCP}$ 상 십이지장 주

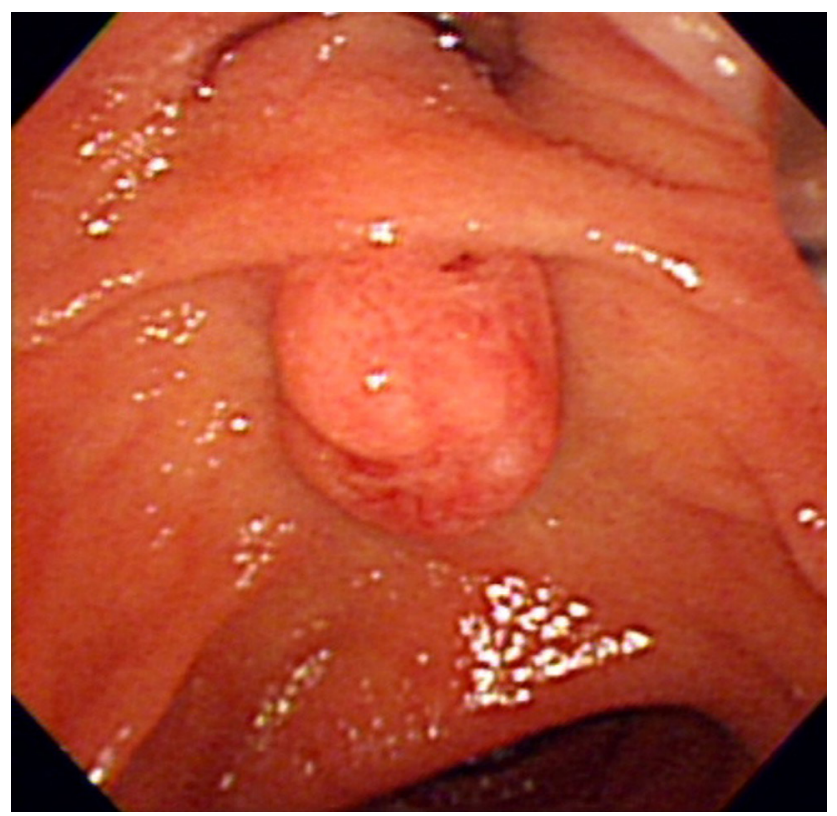

Fig. 2. An endoscopic image shows an enlarged major papilla with central umbilication and nodularity. This differs from the findings of papillitis.

유두는 비대했으나 일반적인 유두염과는 다르게 점막 표면 은 정상이었다. 그러나 유두의 개구부를 포함한 중심부가 함 몰되어 있었고 그 바닥은 결절 모양으로 울퉁불퉁하였다 (Fig. 2). 내시경적 유두괄약근 절제술을 시행한 이후 총 담관 내의 오니를 제거하고 주유두부의 조직 생검을 시행하였다. 조직 검사상 현미경 고배율 시야 열 개에서 유사분열 세포가 관찰되지 않는 신경내분비종양이 진단되었다. 이후 시행한 자기 공명 영상(MRI) 검사에서 십이지장 주유두의 $8 \mathrm{~mm}$ 크 기의 고에코성 병변이 관찰 되었으나, 주변 림프절 전이는 없었다. 신경내분비종양의 담관과 췌관의 침범 여부를 확인 하기 위해 내시경초음파 검사를 권유하였지만, 경제적인 이 유로 추가적인 검사를 거부하였다. 종양의 완전 절제를 위해 수술적 치료를 하자고 하였으나 고령과 수술의 위험도로 수 술적 치료도 거부하였다.

조직학적으로 분화도가 좋고 크기가 $1 \mathrm{~cm}$ 미만이면서 CT 및 MRI 검사에서 담관과 췌관의 침범이나 림프절 전이 소견 이 없어 내시경 유두절제술이 가능할 것으로 판단되어 시행 하였다. 십이지장 주유두의 종양을 확인하고 올가미 $(18 \mathrm{~mm}$, Olympus, 일본)를 이용하여 병변을 잡은 후 약 15 초 정도 고 주파 교류, 엔도-컷 큐모드(Endo-cut Q mode) 60와트를 통 전하여 종양을 절제하였다(Fig. $3 \mathrm{~A})$. 종양 절제 후 담관 및 췌 관에 각각 $7 \mathrm{Fr}, 8 \mathrm{~cm}$ Asian 플라스틱 스텐트(Medi-Globe, 독 

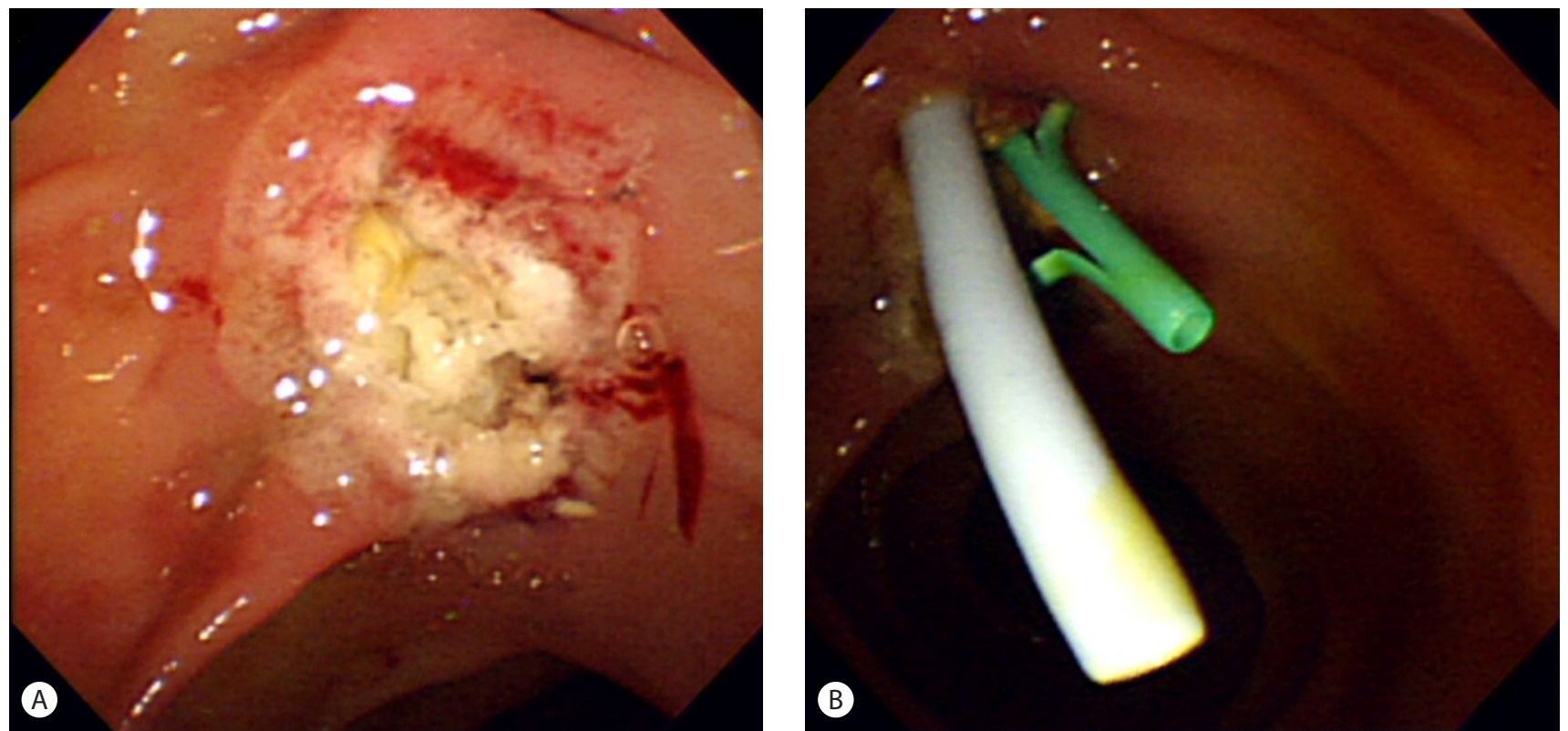

Fig. 3. Endoscopic snare papillectomy is performed. (A) An endoscopic image immediately after papillectomy shows complete resection without complications. (B) Biliary and pancreatic stents are inserted to prevent possible cholangitis and pancreatitis.
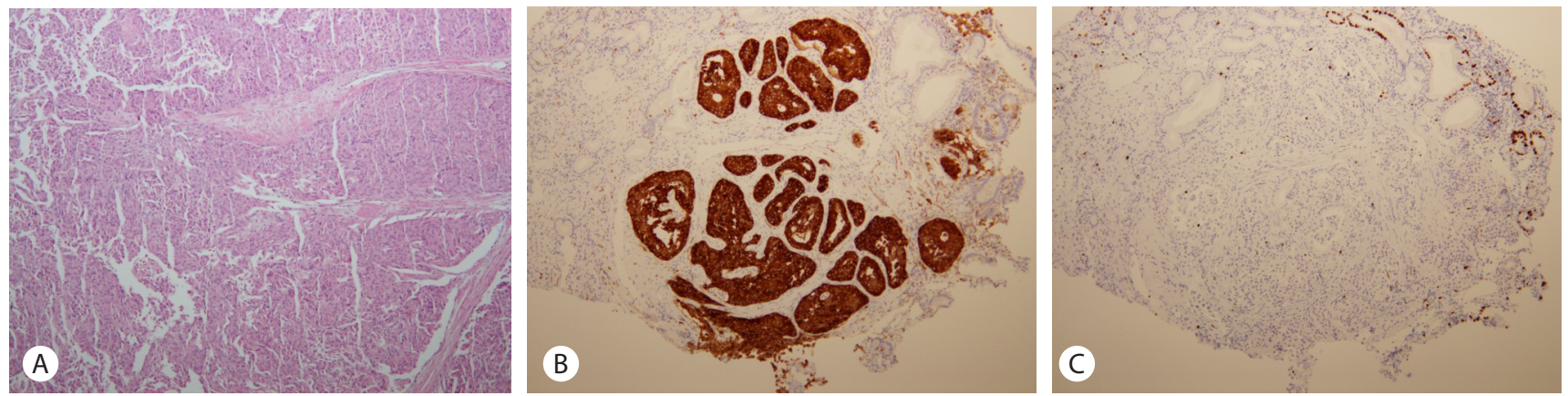

Fig. 4. Microscopic findings of the resected specimen. (A) The tumor shows solid or gyriform features. The cells have round to oval nuclei with fine chromatin. Mitosis is not observed (H-E, x100). (B) The tumor cells show diffuse, strong positivity in synaptophysin immunohistochemical staining (Synaptophysin staining, x200). (C) About 2\% of the tumor cells are positive in Ki-67 immunohistochemical staining (Ki-67 staining, x200).

일), 7Fr, $5 \mathrm{~cm}$ Geenen 플라스틱 스텐트(Wilson-Cook Medicdal, 미국)를 삽입하고 시술을 종료하였다(Fig. 3B).

제거된 종양은 점막하층에 국한된 $0.6 \mathrm{~cm}$ 크기의 경계가 명확한 종괴로 절제연에서 종양세포의 침윤이 관찰되지 않 고 완전 절제되었다. 종양세포는 열 개의 고배율 시야에서 유사분열이 관찰되지 않았으며(Fig. $4 \mathrm{~A}$ ) 신경내분비 표지자 인 synaptophysin에 미만성, 강양성으로 염색이 되었고(Fig. $4 \mathrm{~B}), \mathrm{Ki}-67$ 염색지수가 $2 \%$ 로 측정되어서(Fig. $4 \mathrm{C}$ ) 신경내분 비종양 1 등급으로 최종 진단되었다. 내시경 유두절제술 5 일 뒤, 담관과 췌관에 삽입하였던 스텐트를 모두 제거하였고 내 시경검사결과에서 출혈은 없었다. 이후 특이 합병증 없이 내 시경 절제술 후 9 일만에 퇴원하였다. 2 개월 뒤 시행한 내시
경검사에서도 재발 소견이 없었으며(Fig. 5) 항암화학요법 등 의 다른 추가적인 치료 없이 외래에서 추적 관찰 중이다.

\section{고 찰}

십이지장 주유두의 신경내분비종양은 전세계적으로 약 140 건이 보고되었으며 내시경절제술로 치료한 증례는 6 개 뿐인 드문 질환이다. ${ }^{4,5,-9}$ 일반적으로 신경내분비종양은 세 로토닌 분비를 증가시켜 설사, 화끈거림의 증상을 보이는 카 르시노이드증후군을 유발하나, 십이지장 주유두에서는 이 러한 카르시노이드증후군이 드물다. ${ }^{10}$ 오히려 주유두부의 신 


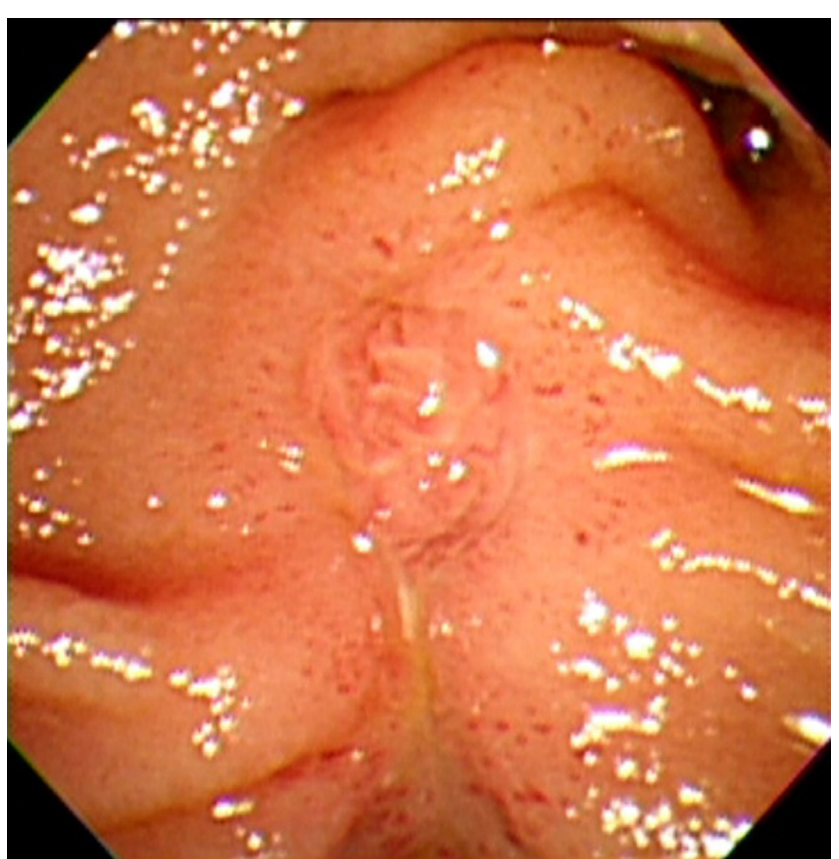

Fig. 5. An endoscopic image at 2 months after papillectomy shows no evidence of tumor recurrence.

경내분비종양은 해부학적으로 담관과 췌관의 합류부에서 발생하여 담관 폐쇄에 따른 폐쇄황달이 $53 \%$ 로 가장 흔하고 복통, 체중감소, 췌장염이 나타날 수 있다. ${ }^{1}$ 그러나 주유두부 의 신경내분비종양의 절반은 무증상으로 우연히 발견되며 국내에서 내시경절제술을 시행한 증례도 건강검진에서 우 연히 발견되어 시행 받은 경우였다. ${ }^{710}$ 본 증례에서도 내원 당시 종양에 의한 증상은 없었다. 주유두부의 신경내분비종 양이라도 종괴에 의한 임상증상은 다른 주유두부 종양과 유 사할 것으로 예상된다. 종괴의 크기가 작은 경우 종괴에 의 한 폐쇄황달 등의 증상이 없을 수 있으며, 조기 병변의 경우 돌출된 주유두 형태로 발견될 수 있다. 본 증례도 응급실 내 원 당시 주 증상이 담낭염에 의한 복통이었고 카르시노이드 증후군은 나타나지 않았다. 담낭 절제술 이후 보인 폐쇄황달 은 신경내분비종양보다는 담석에 의한 것으로 여겨진다. 본 증례와 같이 크기가 작고 무증상인 십이지장 주유두 종양은 CT, MRI와 같은 영상검사로 발견이 어려울 수 있다. 이는 신 경내분비종양뿐 아니라 다른 십이지장 주유두의 종양에서 도 동일하다. 따라서 주유두부의 신경내분비종양의 진단과 조직학적 확진에는 $\mathrm{ERCP}$ 가 가장 정확한 방법이다. 치료 방 향의 결정을 위해서는 복부 CT, MRI 검사를 시행하여 담관 과 췌관내 종양 침윤 정도와 림프절 및 다른 장기로의 전이 유무에 대한 감별이 필요하다. ${ }^{1}$ 영상 검사에서 신경내분비종
양은 혈관이 많아 동맥기 촬영에서 조기에 조영 증강되는 모 습을 보이는데 $10 \%$ 에서는 CT나 MRI에서 보이지 않아 내시 경적 진단이 필요하다. ${ }^{1{ }^{1}}$ 최근에 시행되고 있는 내시경초음 파는 내시경절제술에 중요한 병변의 침범 깊이와 국소화에 대한 정확도가 높아 내시경절제술 후보군 선정의 민감도가 $94 \%$ 에 이른다. ${ }^{12}$ 본 환자에서도 내시경초음파 시행을 고려 하였으나 경제적 사정으로 시행하지 못한 제한점이 있다. 종 양의 완전 절제를 위해 수술적 치료를 고려하였으나 고령과 수술의 위험도로 수술적 치료를 거부하는 상황이었다. 신경 내분비종양은 진행하게 되면 전이를 동반할 수 있는 질환으 로 문헌고찰을 하여 보니 내시경절제술이 가능할 것으로 판 단되어 내시경절제술을 진행하였다.

내시경절제술 여부를 결정하는데 가장 중요한 요소는 종 양의 조직학적 분화도와 림프절 전이 여부이다. 조직학적 분 화도는 종양의 증식 능력에 따라 1 등급, 2 등급, 3 등급으로 분 류한다. 이중 3 등급의 신경내분비종양은 신경내분비암으로 구분한다. 분화도가 좋은 신경 내분비종양의 5 년 생존율은 $79 \%$ 인 반면 신경내분비암의 5 년 생존율은 $40 \%$ 로 두 군간의 통계적으로 유의한 차이가 있다. ${ }^{3}$ 분화도가 좋지 않은 경우 에서 수술이 가능하다면 적극적이고 광범위한 수술적 절제 가 시행된다. ${ }^{3}$ 일반적으로 신경내분비종양에서 림프절 전이 는 크기가 클수록 더 잘 동반되는데 십이지장에서 크기가 2 $\mathrm{cm}$ 이상이면 전이 가능성이 10 배 이상 증가하는 것으로 알 려져 있다. ${ }^{13}$ 하지만, 십이지장 주유두에서의 73 증례를 분석 한 연구에 따르면 종양의 크기가 $2 \mathrm{~cm}$ 이상일 때 $48 \%, 2 \mathrm{~cm}$ 이하일 때 $40 \%$ 에서 림프절 전이를 동반하는 것으로 보고되 어 종양의 크기와 전이 가능성은 직접적인 연관성이 없었 다. ${ }^{14}$ 십이지장 주유두 신경내분비종양은 작은 크기에서도 림프절 전이가 가능하기 때문에 완전 절제가 권고된다. 십이 지장 주유두에 발생한 신경내분비종양에서 림프절 절제를 위해서는 Kausch-Whipple 수술이나 위유문보존 췌장십이 지장절제술이 시행되는데, 수술과 관계된 사망률은 약 $5 \%$, 합병증 발생률은 $15 \%$ 이다. ${ }^{1}$ 따라서, 수술에 따른 위험도를 낮추기 위해 종양의 분화도가 좋고 림프절 전이가 없는 경우 림프절 절제 없는 외과적 국소 절제술을 고려할 수 있으며 췌십이지장절제술과 비교하였을 때 장기 생존율이 유사하 다. ${ }^{3,6}$ 92명의 십이지장 주유두 신경내분비종양 환자에서 수 술 후 합병증으로 사망한 경우는 췌십이지장절제술군이 $5.7 \%$ 인 3 명이었고, 수술적 국소 절제술군에서는 0 명이었다. 수술 후 10 년간 추적 관찰하였을 때 췌십이지장절제술을 받 
Table 1. Summary of patients with ampullary neuroendocrine tumor treated via endoscopic papillectomy

\begin{tabular}{|c|c|c|c|c|c|c|c|c|c|c|c|}
\hline \multirow{2}{*}{$\begin{array}{l}\text { Authors } \\
\text { (published year) }\end{array}$} & \multirow{2}{*}{$\begin{array}{l}\text { Age/ } \\
\text { Sex }\end{array}$} & \multirow{2}{*}{$\begin{array}{l}\text { Tumor } \\
\text { Size } \\
\text { (cm) }\end{array}$} & \multirow[b]{2}{*}{$\mathrm{CT}$} & \multicolumn{2}{|c|}{ Pre-evaluation } & \multirow[b]{2}{*}{ EUS } & \multirow[b]{2}{*}{$\begin{array}{c}\text { Pre-papillectomy } \\
\text { biopsy }\end{array}$} & \multirow{2}{*}{$\begin{array}{c}\text { Final } \\
\text { pathology }\end{array}$} & \multirow[b]{2}{*}{ complication } & \multirow{2}{*}{$\begin{array}{c}\mathbf{f} / \mathbf{u} \\
\text { duration }\end{array}$} & \multirow[b]{2}{*}{ Recurrence } \\
\hline & & & & MRI & $\begin{array}{l}\text { Octreotide } \\
\text { Scan }\end{array}$ & & & & & & \\
\hline $\begin{array}{l}\text { Yi H et al. } \\
(2012)\end{array}$ & $67 / F$ & 2.5 & 0 & 0 & - & 0 & N/A & $\begin{array}{l}\text { Low grade } \\
\text { NET }\end{array}$ & None & $6 \mathrm{mo}$ & No \\
\hline $\begin{array}{l}\text { Odabasi M et al. } \\
\text { (2013) }\end{array}$ & $45 / F$ & 2 & 0 & - & 0 & 0 & $\begin{array}{c}\text { Low grade } \\
\text { NET }\end{array}$ & $\begin{array}{l}\text { Low grade } \\
\text { NET }\end{array}$ & None & $14 \mathrm{mo}$ & No \\
\hline $\begin{array}{l}\text { Gilani N et al. } \\
(2007)\end{array}$ & $71 / \mathrm{M}$ & 1.5 & 0 & - & 0 & 0 & $\begin{array}{c}\text { Low grade } \\
\text { NET }\end{array}$ & $\begin{array}{l}\text { Low grade } \\
\text { NET }\end{array}$ & Minor bleeding & $3 \mathrm{yr}$ & No \\
\hline $\begin{array}{l}\text { Bae SH et al. } \\
\text { (2014) }\end{array}$ & $31 / M$ & 3 & 0 & 0 & - & 0 & $\begin{array}{c}\text { Low grade } \\
\text { NET }\end{array}$ & $\begin{array}{l}\text { Low grade } \\
\text { NET }\end{array}$ & None & N/A & N/A \\
\hline $\begin{array}{l}\text { Pyun DK et al. } \\
(2004)\end{array}$ & $62 / \mathrm{M}$ & 0.7 & 0 & - & 0 & 0 & $\begin{array}{c}\text { Low grade } \\
\text { NET }\end{array}$ & $\begin{array}{l}\text { Low grade } \\
\text { NET }\end{array}$ & None & $6 \mathrm{mo}$ & No \\
\hline This case & $73 / \mathrm{M}$ & 0.6 & 0 & 0 & - & - & $\begin{array}{c}\text { Low grade } \\
\text { NET }\end{array}$ & $\begin{array}{c}\text { Low grade } \\
\text { NET }\end{array}$ & None & $2 \mathrm{mo}$ & No \\
\hline
\end{tabular}

M, male; F, female; N/A, not available; NET, neuroendocrine tumor; mo, month; yr, years; f/u, follow up.

은 환자 군에서 간 전이로 3 명이 사망하여 총 6 명이 사망하 였고, 수술적 국소 절제술군에서는 1 명이 국소재발, 3 명이 전이로 총 4 명이 사망하여 두 군 사이의 장기적인 예후에서 유의한 차이를 보이지 않았다. ${ }^{6}$

최근에는 수술에 따른 합병증과 위험도가 높거나 담관 및 췌관에 침범이 없는 주유두 신경내분비종양 환자에서 수술 적 치료가 아닌 내시경절제술이 시도되고 있다. ${ }^{1,15}$ 췌십이지 장절제술과 비교하였을 때 내시경 유두절제술은 사망률이 낮고, 입원기간도 짧았으며 이 또한 완전 절제를 할 수 있어 국소 절제가 가능한 십이지장 주유두 신경내분비종양에 있 어 하나의 치료적 대안으로 고려해 볼 수 있겠다.

십이지장 주유두에서 발생한 신경내분비종양의 내시경 유 두절제술은 국내에 3건, 국외에 3건 시행 되었으며(Table 1) 현재까지 보고된 증례 대부분은 병변의 크기가 $2 \mathrm{~cm}$ 이하였 지만 $2.5 \mathrm{~cm}$ 와 $3 \mathrm{~cm}$ 에서 시행한 증례가 1 개씩 있었다. 모든 증례에서 시술 전 검사로 $\mathrm{CT}$ 를 시행하였고, MRI는 3 개, Octreotide scan 3 개, EUS는 5개의 증례에서 시행되었다. 유 두절제술 전과 후의 조직학적 소견은 차이가 없었다. 합병증 으로는 1 개의 증례에서 시술 후 약간의 출혈이 있어 에피네 프린 주입 시행 후 지혈 되었으며 그 외 보고된 합병증은 없 었다. ${ }^{4-8}$ 본 증례에서는 기존의 증례에서 시술 전 검사로 시행 된 내시경초음파를 하지 못했고, 신경내분비종양의 크기는 국내에서 보고한 $3 \mathrm{~cm}$ 보다 작은 비교적 일반적으로 내시경 절제술이 시행되는 크기였으며 기존에 보고된 증례들과 마
찬가지로 재발은 보이지 않았다.

십이지장 주유두 신경내분비종양의 내시경절제술에 따른 합병증은 유두부 종괴에 대한 통상적인 내시경 유두절제술 후 발생하는 합병증과 차이가 없을 것으로 예상되나 아직까 지 보고된 증례가 적어 정확한 치료적 유용성이나 안정성을 규정하기는 어렵다. 또한 수술적 치료와의 비교가 되어 있지 않아 시술의 유용성과 합병증, 예후에 대한 연구가 더 필요 한 상태이다. 다만 내시경 유두절제술이 많이 시행되는 십이 지장 주유두 선종에서의 경우를 보면, 시술 후 합병증으로는 췌장염과 출혈이 가장 많았고 합병증의 발생률은 8-35\%였 다. 대부분의 출혈은 내시경적 지혈과 대증적 치료로 조절되 었다. 시술에 따른 사망률은 $0.4 \%$, 재발률은 $20 \%$ 를 보였는 데, 재발에 관련된 인자로는 종양의 크기와 조직학적 소견, 췌관 및 담관내 침범 여부, 그리고 내시경 시술자의 숙련도 등이 보고되었다. ${ }^{15}$

본 증례는 담관 및 췌관의 침범이 없고, 림프절이나 다른 장기로의 전이가 없는 신경내분비종양 1 등급 환자에서 내시 경 유두절제술을 시행한 증례이다. 제거된 종양은 조직 검사 상 완전 절제 되었고 현미경 고배율 시야 열 개에서 유사 분 열수가 관찰되지 않으며 Ki-37 지수 2\% 미만으로 예후가 좋 은 것으로 알려진 신경내분비종양 1 등급에 합당하였다. 시 술 후 2 개월째 시행한 검사에서 재발을 시사하는 소견은 없 었으나 지속적인 추적 관찰이 필요하겠다. 


\section{요 약}

신경내분비종양은 드물지만 완전 절제가 필요한 종양으로 십이지장 주유두에 발생한 경우 췌십이지장절제술이 권고 되어 왔다. 하지만 수술에 따른 위험도를 고려할 때, 분화도 가 좋고 전이가 없으며 췌관이나 담관에 침범이 없는 선택된 경우에 한해서 내시경절제술이 시도되고 있다. 이번 증례는 내시경 유두절제술을 통하여 신경내분비종양을 완전히 절 제하는데 성공한 증례로 십이지장 주유두 신경내분비종양 에 있어서 수술에 대한 위험도가 높을 경우 내시경절제술이 대안이 될 수 있음을 보여주었다.

국문 색인: 신경내분비종양, 바터팽대부종양, 십이지장 주유 두, 유두절제술

\section{Conflicts of Interest}

No conflict among authors

\section{REFERENCES}

1. Hartel M, Wente MN, Sido B, Friess H, Büchler MW. Carcinoid of the ampulla of Vater. J Gastroenterol Hepatol 2005;20:676-681.

2. Jayant M, Punia R, Kaushik R, et al. Neuroendocrine tumors of the ampulla of vater: presentation, pathology and prognosis. JOP J Pancreas 2012;13:263-267.

3. Strosberg JR, Weber JM, Feldman M, Coppola D, Meredith K, Kvols LK. Prognostic validity of the American Joint Committee on Cancer staging classification for midgut neuroendocrine tumors. J Clin Oncol 2013;31:420-425.

4. Yi $H, W u ~ C, M o u ~ Y$, et al. Successful en bloc resection of papillary neuroendocrine tumors by duodenoscope using endoscopic submuco- sal dissection method. Clin Res Hepatol Gastroenterol 2012;36:e100103.

5. Odabasi M, Yildiz KM, Cengiz E, et al. Treatment of ampullary neuroendocrine tumor by endoscopic snare papillectomy. Am J Case Rep 2013;14:439-443.

6. Gilani N, Ramirez FC. Endoscopic resection of an ampullary carcinoid presenting with upper gastrointestinal bleeding: a case report and review of the literature. World J Gastroenterol 2007;13:1268-1270.

7. Bae S-H, Kim JY, Kim CL, et al. A large neuroendocrine tumor of the major duodenal papilla removed by endoscopic papillectomy. Korean Journal of Medicine 2014;86:319.

8. Pyun DK, Moon G, Han J, et al. A carcinoid tumor of the ampulla of Vater treated by endoscopic snare papillectomy. Korean J Intern Med 2004;19:257-260.

9. Albores-Saavedra J, Hart A, Chable-Montero F, Henson DE. Carcinoids and high-grade neuroendocrine carcinomas of the ampulla of vater: a comparative analysis of 139 cases from the surveillance, epidemiology, and end results program-a population based study. Arch Pathol Lab Med 2010;134:1692-1696.

10. Onaitis MW, Kirshbom PM, Hayward TZ, et al. Gastrointestinal carcinoids: characterization by site of origin and hormone production. Ann Surg 2000;232:549-556.

11. Ganeshan D, Bhosale P, Yang T, Kundra V. Imaging features of carcinoid tumors of the gastrointestinal tract. AJR Am J Roentgenol 2013;201:773-786.

12. Kim MK. Endoscopic ultrasound in gastroenteropancreatic neuroendocrine tumors. Gut Liver 2012;6:405-410.

13. Clements WM, Martin SP, Stemmerman G, Lowy AM. Ampullary carcinoid tumors: rationale for an aggressive surgical approach. J Gastrointest Surg 2003;7:773-776.

14. Hatzitheoklitos E, Büchler MW, Friess H, et al. Carcinoid of the ampulla of Vater. Clinical characteristics and morphologic features. Cancer 1994;73:1580-1588.

15. De Palma GD. Endoscopic papillectomy: indications, techniques, and results. World J Gastroenterol 2014;20:1537-1543. 